\title{
A Mobile Encapsulation and Volume Reduction System for Wet Low-Level Wastes
}

\author{
J. L. Buelt
}

August 1985

Prepared for the U.S. Department of Energy under Contract DE-AC06-76RLO 1830

Pacific Northwest Laboratory Operated for the U.S. Department of Energy by Battelle Memorial Institute 


\title{
DISCLAIMER
}

This report was prepared as an account of work sponsored by an agency of the United States Government. Neither the United States Government nor any agency thereof, nor any of their employees, makes any warranty, express or implied, or assumes any legal liability or responsibility for the accuracy, completeness, or usefulness of any information, apparatus, product, or process disclosed, or represents that its use would not infringe privately owned rights. Reference herein to any specific commercial product, process, or service by trade name, trademark, manufacturer, or otherwise, does not necessarily constitute or imply its endorsement, recommendation, or favoring by the United States Government or any agency thereof. The views and opinions of authors expressed herein do not necessarily state or reflect those of the United States Government or any agency thereof.

\author{
PACIFIC NORTHWEST LABORATORY \\ operated by \\ BATTELLE \\ for the \\ UNITED STATES DEPARTMENT OF ENERGY \\ under Contract DE-AC.06-76RLO 1830
}

Printed in the United States of America

Available from

National Technical information Service United States Department of Commerce

5285 Port Royal Road

Springfield, Virginia 22161

NTIS Price Codes

Microfiche $A 01$

Printed Copy

$\begin{array}{ll}\text { Pages } & \text { Price } \\ \text { Codes }\end{array}$

001-025

026-050 A03

051-075 A04

076-100 A05

101-125 A06

126-150 $\quad A 07$

151-175 A06

176-200 $\quad A 09$

201-225 A010

226-250 $\quad$ A011

251-275 A012

276-300 $\quad 013$ 
PNL -5533

UC -708

A MOBILE ENCAPSULATION AND VOLUME REOUCTION SYSTEM FOR WET LOW-LEVEL WASTES

J. L. Buelt

August 1985

Prepared for the U.S. Department of Energy under Contract DE-AC06-76RLO 1830

Pacific Northwest Laboratory

Richland, Washingt on 99352 


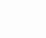




\section{SUMMARY}

This report describes the results of the program entitled "A Preconceptual Study for a Transportable Vitrification Process". The objective of the study is to determine the feasibility of a Mobile Encapsulation and Volume Reduction System (MEVS). The report contains design criteria, a preconceptual design of the system, a comparison of disposal costs with other solidification technologies, and an assessment of utility interests in the transportable volume reduction service MEVS can provide.

The MEVS design employs the use of a joule-heated glass melter to convert the wet low-level wastes into glass. The waste is converted to a stable form, suitable for geologic disposal, and a high volume reduction is achieved. The process is self-sufficient, requiring no direct facility services or reactor personnel. It is capable of servicing one waste type from a minimum of three reactors. It can process $360 \mathrm{~m}^{3} / \mathrm{yr}\left(12,700 \mathrm{ft}^{3} / \mathrm{yr}\right)$ of resins or $1080 \mathrm{~m}^{3} / \mathrm{yr}$ $\left(38,100 \mathrm{ft}^{3} / \mathrm{yr}\right)$ of concentrated liquid.

The design was used to prepare capital and operating cost estimates. The capital cost for the MEVS is $\$ 4,680,000$, which includes all labor necessary for design, engineering, inspection, and licensing. The operating cost of the system for servicing a minimum of three reactors is $\$ 1,530,000 / y r$ for resins or $\$ 2,280,000 / y r$ for concentrated liquids. The cost estimates compared favorably to the more common solidification process of cementation. Total MEVS operating costs which include processing, transportation and burial, are $\$ 191$ to $\$ 218 / \mathrm{ft}^{3}$ waste, whereas quoted costs for cementation and disposal from reactor operators range from $\$ 155$ to $\$ 350 / \mathrm{ft}^{3}$. MEVS costs also compared favorably with estimates of alternative solidification processes when compared on an equivalent basis.

The report concludes with the requirements for additional development, which can be accomplished for less than one sixth of the capital costs. The report also presents the results of an assessment conducted with utility representatives to obtain their expressions of interest in a service of this type. 



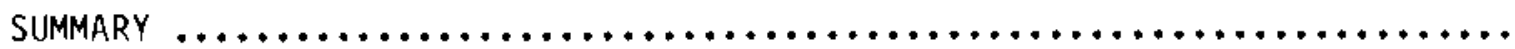

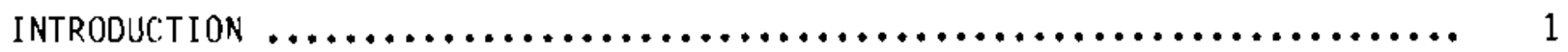

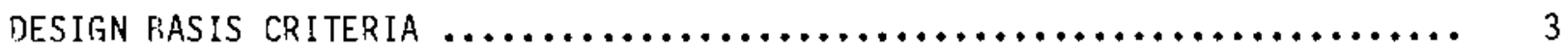

PRECONCEPTUAL DESIGN $\ldots \ldots \ldots \ldots \ldots \ldots \ldots \ldots \ldots \ldots \ldots \ldots \ldots \ldots \ldots \ldots \ldots \ldots \ldots \ldots$

ARCHITECTURAL AND STRUCTURAL $\ldots \ldots \ldots \ldots \ldots \ldots \ldots \ldots \ldots \ldots \ldots \ldots \ldots \ldots \ldots \ldots \ldots \ldots \ldots \ldots$

The Process Trailer ............................. 7

The Control Trailer .............................. 11

Support Trailer ................................ 11

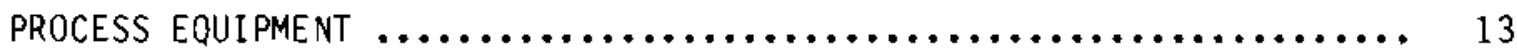

Special Equipment $\ldots \ldots \ldots \ldots \ldots \ldots \ldots \ldots \ldots \ldots \ldots \ldots \ldots \ldots \ldots \ldots$

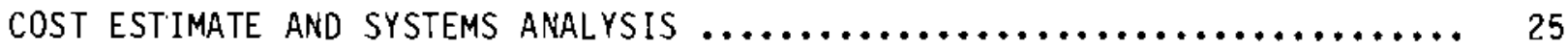

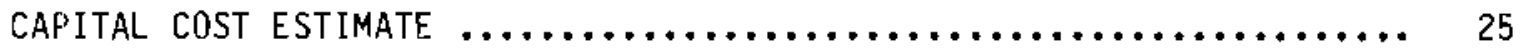

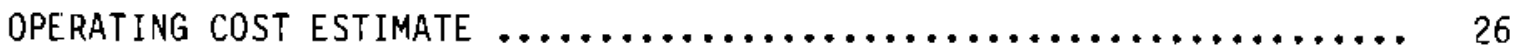

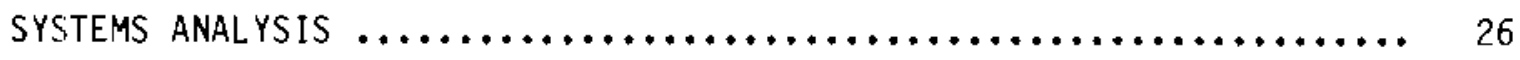

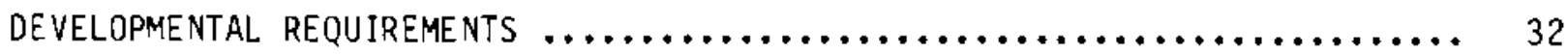

UTILITY ASSESSMENT $\ldots \ldots \ldots \ldots \ldots \ldots \ldots \ldots \ldots \ldots \ldots \ldots \ldots \ldots \ldots \ldots \ldots \ldots \ldots \ldots \ldots$

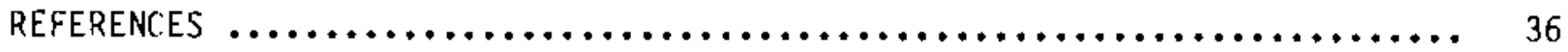

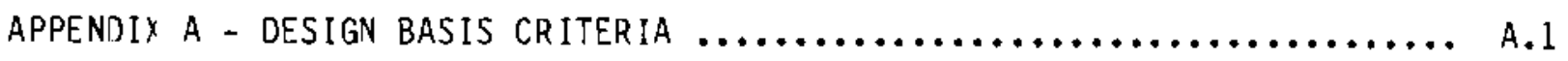

APPENDI $\rangle$ B - OPERATING COST ESTIMATE $\ldots \ldots \ldots \ldots \ldots \ldots \ldots \ldots \ldots \ldots \ldots \ldots \ldots$ 


\section{FIGURES}

1 The Joule-heated Gilass Melter for the MEvs $\ldots \ldots \ldots \ldots \ldots \ldots \ldots \ldots \ldots$

2 The Process Trailer $\ldots \ldots \ldots \ldots \ldots \ldots \ldots \ldots \ldots \ldots \ldots \ldots \ldots \ldots \ldots \ldots \ldots$

3 Control and Support Trailers $\ldots \ldots \ldots \ldots \ldots \ldots \ldots \ldots \ldots \ldots \ldots \ldots \ldots \ldots \ldots$

4 Process Flow Diagram $\ldots \ldots \ldots \ldots \ldots \ldots \ldots \ldots \ldots \ldots \ldots \ldots \ldots \ldots \ldots \ldots \ldots \ldots$

5 Scrub Solution Flow Diagram $\ldots \ldots \ldots \ldots \ldots \ldots \ldots \ldots \ldots \ldots \ldots \ldots \ldots \ldots \ldots$

\section{TABLES}

1 A Comparison of Disposal Costs for Cementation and MEVS ......... 28

2 A Comparison of Disposal Costs for Cementation and MEVS .......... 30

3 Disposal Costs Using Assumptions by Jacobs et al. in January

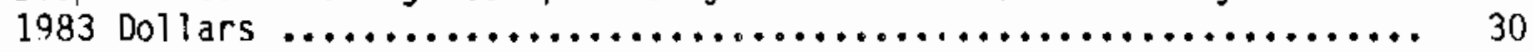

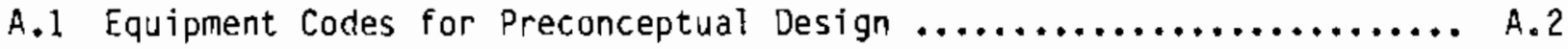

A.2. Annual Generation Rates and Curie Inventorjes for

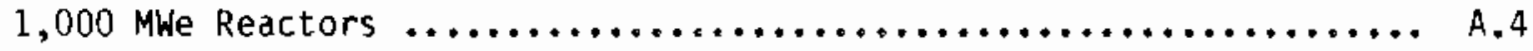


INTRODUCTION

The purpose of this document is to provide the technical data base, conceptual design, and cost estimate for a mobile encapsulation and volume reduction system (MEVS) to be utilized for reactor wet waste processing. The MEVS is basically a glass melting system with enough peripheral equipment to be self-sufficient under all kinds of environments (e.g., transportation, operation, máintenance). The ultimate objective of the MEVS is to reduce the volume of commercially generated low-leve? wet wastes at multiple reactor sites and incorporate the associated radionuclides into a chemically inert glass product.

The MEVS is based on an adaptation of high-level nuclear waste vitrification technology. This technology has been under development and testing for ten years at Pacific Northwest Laboratory ( $P N L$ ) utilizing the joule-heated glass melter (Bjorklund and Brouns 1982). Data collected from those tests encompass different glass melter sizes and capacities. Presently, direct liquid feeding of high-level wastes to the melter has become the front runner of nuclear waste processing technology at Hanford, Savannah River, and West valley. The application of this technology to low-level wet wastes started in 1982 when the joule-heated melter was successfully tested at PNL with combustible wet resins (Buelt 1982). Another low-level waste application of this technology has been carried out by Monsanto Research Laboratory where a version of the joule-heated melter vitrified a variety of combustible wastes (Klingler and Armstrong 1984).

The MEVS consists of the joule-heated glass melter, its associated feed system, an off-gas treatment system, and a product handling and transfer station. It is located in a mobile assembly of tractor/trailers. The system is designed to be transported to a number of nuclear reactor sites to process lowlevel wet wastes generated and stored on the site. The end product incorporates the noncombustible portions and the inherent radionuclides of the wastes into glass, a stable monolithic and inert solid.

This document provides the basic design criteria of the MEVS, its preconceptual design, the capital and operating cost estimates and comparisons, developmental needs, and utility assessment. 



\section{DESIGN BASIS CRITERIA}

The design basis criteria has been established to provide the technical data base for the preconceptual design. The criteria served as the prime guideline for establishing the preconceptual design and is reported in Appendix A. 
, 


\section{PRECONCEPTUAL DESIGN}

The Mobile Encapsulation and Volume Reduction system (MEVS) has been preconceptually designed to meet the design basis criteria. The process is designed to destroy and/or reduce the volume of wet waste produced by commercial nuclear reactors. The process is specifically adapted towards slurries of filter sludges, evaporator bottoms, and ion exchange resins. It is capable of handling both noncombustible and combustible slurries without pre-evaporation or other pretreatment steps. The slurries are dried and/or decomposed in a glass melter which combusts the organic constituents and incorporates the radionuclides and nonvolatile byproducts into a glass matrix, thereby attaining a large volume reduction of the waste. The glass is then poured into drums which can be used to minimize on-site storage requirements or reduce transportation and burial costs.

The heart of the MEVS is the joule-heated glass melter, shown in Figure 1. The glass melter has been specially adapted to process both noncombustible and combustible slurries. A special feeding technique for each of these wastes helps incorporate the radionuclides directly into the glass, minimizing particulate carryover and volatilization into the gaseous effluent stream. Radionuclides that are volatilized are scrubbed from the gaseous effluents via an off-gas treatment system. The scrub solution is decontaminated and recycled back to the plant through an ion exchange column which is included in the MEVS. After being fully loaded, the ion exchange resins in the column are recycled back to the melter, thereby eliminating any secondary waste stream generation.

The process can be categorized into six basic groups: 1) the feed system, 2) the melter system, 3) the product handling area, 4) the off gas treatment system, 5) the control area, and 6) the electrical and cooling support equipment. All of the components of the process are located on three transportable semi-trailers. The process is entirely self-contained requiring no facilitytype services from the reactor for operations. 


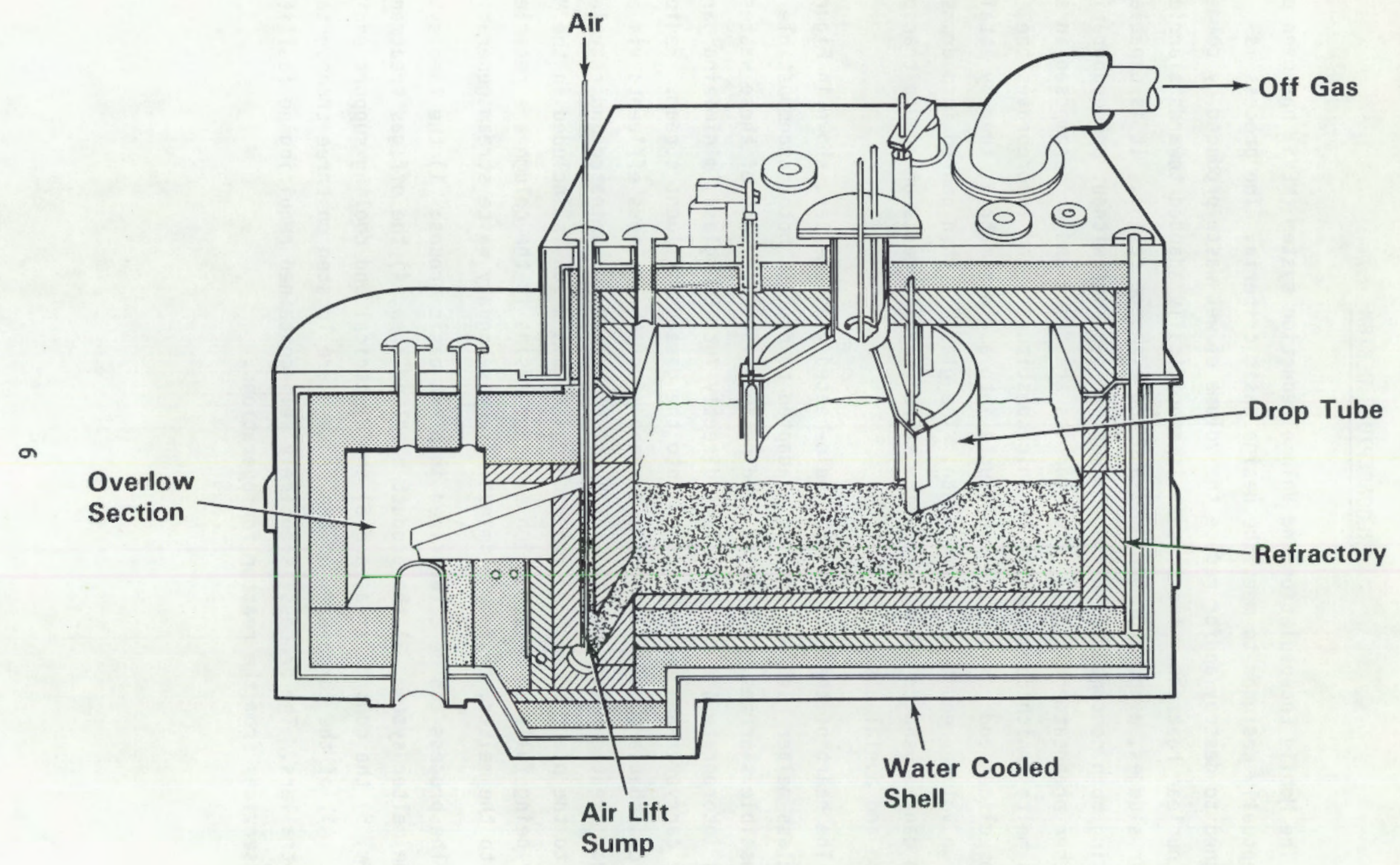

FIGURE 1. The Joule-Heated Glass Melter for the MEVS 
The preconceptual design, which has been produced in a PNL program supported by the Department of Energy, is presented in drawings on file which include the following:

- Engineering Flow Diagram (SK-3-26331, Sheets 1-2)

- Piping and Instrument Diagrams (SK-3-26332, Sheets 1-4)

- Process Trailer Assembly (SK-3-26333, Sheet 1)

- Melter Assembly (SK-3-26334, Sheets 1-2)

- Turntable Assembly (SK-3-26335, Sheet 1)

- Support and Control Trailer Assemblies (SK-3-26336 Sheet 1)

These drawings were used to establish the capital and operating cost estimates for the MEVS. This section of the document provides a narrative description of the functions and size of each of the pieces of equipment.

\section{ARCHITECTURAL AND STRUCTURAL}

The MEVS is contained within three standard semi-trailers, which include the process trailer, the support trailer, and the control trailer. Locating the process equipment in the semi-trailers allows movement of the process from one reactor site to the next. This satisfies the design basis criteria of being able to service more than one reactor site.

\section{The Process Trailer}

All the radioactive processing equipment is contained within one trailer the process trailer (shown in Figure 2). This trailer is a standard highway trailer measuring 14.6 (48 ft) long by $2.6 \mathrm{~m}(8.5 \mathrm{ft})$ wide by $4.1 \mathrm{~m}(13.5 \mathrm{ft})$ high. As per the design criteria, the maximum weight of the trailer, including all process equipment, the trailer, and the towing vehicle, does not exceed $39000 \mathrm{Kg}(86,000 \mathrm{lbs})$.

The trailer adopts a double containment philosophy for all radioactive processing equipment. The first level of containment is the radioactive processing equipment and piping; the second level is a containment module which completely envelopes the radioactive processing equipment. The containment module and trailer structure are designed with removable panels at selected locations for access to allow contact maintenance of the radioactive processing equipment. 


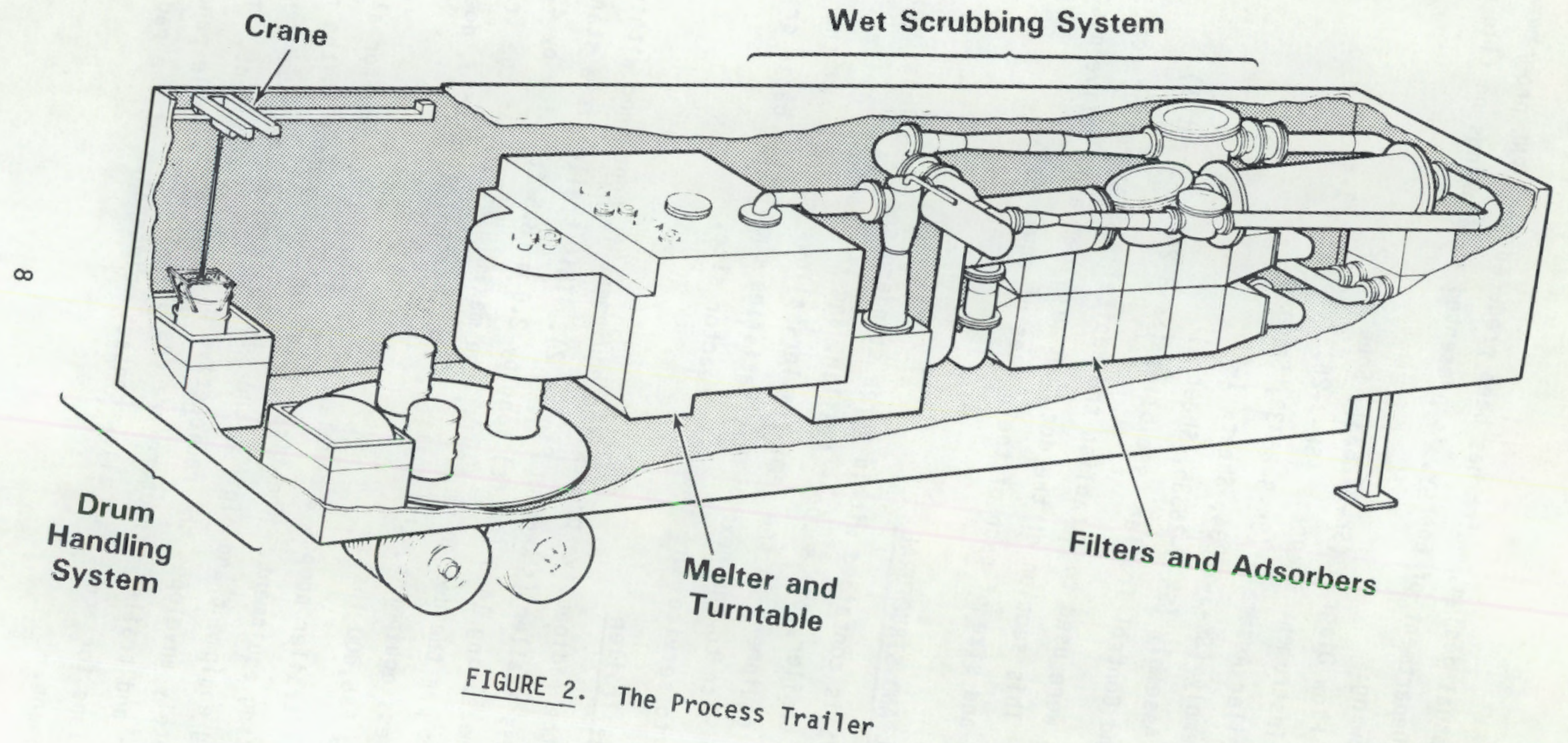


The processing equipment contained within the trailer includes the following:

- Recirculating slurry pump, which pumps wet waste from the plant to the melter feed tank

- $110 \mathrm{~L}$ (40 gal) feed tank with air sparger, in which glass formers are added to the wet waste

- Air displacement feed metering pump, which meters slurry to the melter

- Melter

- Single pass heat exchanger and pump for the melter cooling water

- Turntable, which provides a sealed drum filling and changeout station for glass pouring operations

- Receiving canister station, which places filled drums into an overpack for storage and/or transport

- Venturi scrubber, which provides the first stage of cooling and cleanup for the gaseous effluents

- Two tandem nozzle scrubber units - one with a 12-in. inlet, the other with a 6-in. inlet

- Two mist eliminators, one for each scrubber system, to remove water droplets from the gaseous effluents

- Two single-pass heat exchangers for removing heat from the scrub solution

- Scrub recirculation tank

- Two scrub recirculation pumps

- Resin column for discharge of the scrub solution back to the reactor plant

- Condensor, which removes additional heat from the gaseous effluents

- Mist eliminator after the condensor, which removes droplets generated in the condenser 
- Heater to preheat the air prior to entry to the filtration system

- Two redundant high-efficiency particulate air (HEPA) filter and iodine absorber systems, which provide primary and secondary filtration as well as iodine removal before the gases are exhausted to the reactor plant.

The containment module is vented through a blower and HEPA filter system of equal capacity to that of the process effluent system. Therefore, the containment module ventilation system acts as a full capacity backup to the main process effluent system should it become plugged or have a complete breach in the system.

The process trailer is also equipped with a glass former feed system which is mounted on top of the trailer and removed before transport. The process trailer does not include the induced draft blowers for the containment module and process effluent stream. However, the gases leaving the process trailer are fully decontaminated, thereby meeting the criteria of keeping all radioactive processing equipment in one trailer.

The process trailer is designed for installation of shielding around the melter, product handling areas, and feed tank prior to operation. The 5-cmthick shielding is removable to maintain the weight limitations of $39,000 \mathrm{~kg}$ for transport. After transport to the reactor site, the shielding will be mounted externally to the process trailer around the melter and mounted internally between the melter and effluent treatment system. The internal shielding can be dropped into place through a baffle in the roof of the containment module. The off-gas treatment system requires no shielding. The shielding thickness is based upon the design basis criteria of this report. The radioactive source in the melter and feed tank is assumed to be $100 \mathrm{R} / \mathrm{h}$ using $100 \% \mathrm{Co}^{60}$ as the source for conservatism in the calculations. The maximum dose rate allowable 1 meter from the outside of the trailer is $100 \mathrm{mR} / \mathrm{h}$. After operation, the melter will be drained, the glass product removed, and the system decontaminated to meet the $10 \mathrm{mR} / \mathrm{h}$ criterion 2 meter away from the trailer with the shielding removed. 
The Control Trailer

The control and support trailers are depicted in Figure 3. The control trailer measures $13.7 \mathrm{~m}(45 \mathrm{ft})$ long $\times 2.4 \mathrm{~m}(8 \mathrm{ft})$ wide $\times$ a maximum height of $4.1 \mathrm{~m}(13.5 \mathrm{ft})$; its weight is within the federal highway standards of 36,000 $\mathrm{kg}(80,000$ lbs $)$. All process monitoring and control functions are conducted from the control trailer. The control trailer includes a $5.5 \mathrm{~m} \times 2.4 \mathrm{~m}$ control room which houses the distributed process control system. This system controls all critical operating functions as well as monitors and records on disk and print paper all operating functions of the process. The distributed control system contains inherent redundancy features such as multiple operator interface units, dual plant communication loops, and backup multifunction controllers to ensure safe operation. The control trailer also contains the induced draft blowers for the containment module ventilation and process effluent stream. The two blowers are interconnected such that the two ventilation streams can be directed through either blower should one fail. Therefore, the blowers for process effluent system and the containment module ventilation system are completely redundant. Between the blower system and the control room is a chemical make-up tank which is used for storage and make-up for new scrub solutions. This area also houses the plasma torch power supplies used for restart of the melter.

Support Trailer

The support trailer is a standard flat bed trailer which measures $14.6 \mathrm{~m}$ (48 ft) long $\times 2.6 \mathrm{~m}(8.5 \mathrm{ft})$ wide with a total system capacity including tractor trailer and load of $39,000 \mathrm{~kg}(86,000 \mathrm{lbs})$. It houses all peripheral support equipment which include the electrical and off gas cooling units. The heat exchangers in the process trailer use as a cooling fluid giycol recirculated from the glycol cooler unit located on the support trailer. Blowers located in the glycol cooler unit discharge the heat from the glycol loop to the atmosphere. Three diesel generators are also included on the support trailer for primary and emergency electrical power. The first is a $400 \mathrm{KVA}$, single phase diesel generator for the melter power. The other two are 230 KVA generators for primary and emergency backup power to the off-gas system. The support trailer also contains the 400 KVA transformer and silicon controlled 

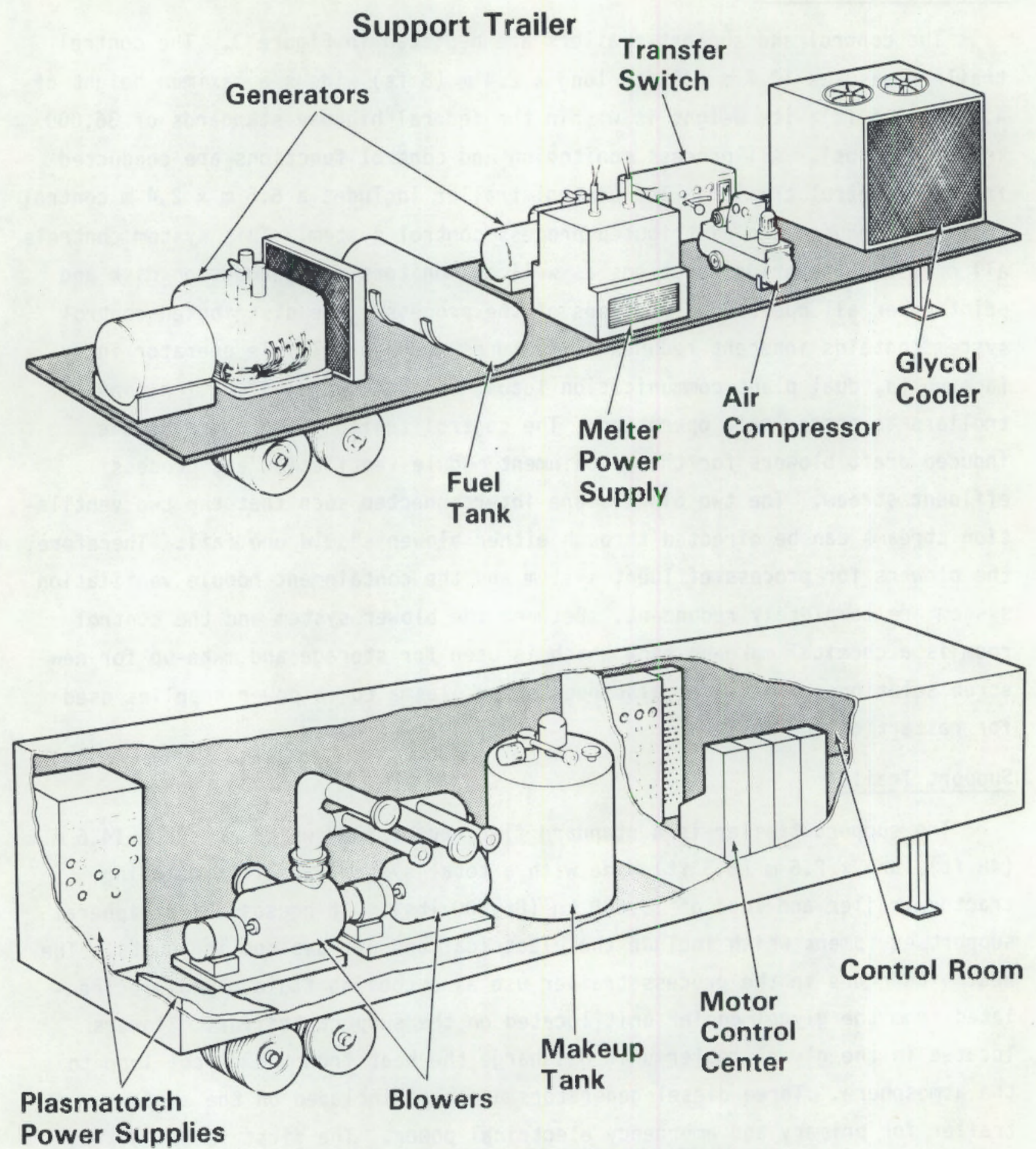

Control Trailer

FIGURE 3. Control and Support Trailers 
rectifier (SCR) which provides the varying voltage and current required for operation. The off-gas system generators are directly connected to an automatic transfer switch and a motor control center which provides $480 \mathrm{~V}$ power to the blowers and motors of the off-gas treatment system. They also provide 480volt power to a step-down 50 kVA transformer which supplies lower voltage servicing through the distribution panel. Lastly, the support trailer contains a 10-HP air compressor for actuation of the pneumatic valves located throughout the process.

Al 1 three trailers are designed to have removable undercarriage assemblies so that they can be transported easily by rail. They will also have pick points near the undercarriage assembly for lifting by crane for loading onto the railcars.

\section{PROCESS EQUI PMENT}

The process equipment needed for the MEVS is composed of specially designed and standardly available equipment. The preconceptual design provides signifisantly more detail for specially designed equipment (i.e., melter and turntable assembly) than for standard equipment. The standard equipment is called sut on the prints by a general description and a recommended manufacturer's model number. The manufacturer is specified solely for the purpose of estaslishing a basis for the capital cost estimate.

Special Equipment

The melter is designed to reduce the volume of both noncombustible and combustible slurries and incorporate their residual radionuclides into a stable glass matrix. The melter processes wet wastes by evaporating or decomposing any volatile components and incorporating the radionuclides and noncombustible portions into a glass matrix. The wet wastes are fed to a molten glass pool which is kept at $1000^{\circ} \mathrm{C}$ to $1100^{\circ} \mathrm{C}$ by introducing an electrical current between Inconel $690^{\circ}$ electrodes at opposite ends of the melting cavity. The glass is contained within the melting cavity lined by a fused-cast refractory known as

- Inconel 690 is a registered trademark of the Huntington Alloys Corporation, Huntington, Alabama. 
Monofrax $\mathrm{K}^{\text {* }}$. As electrical potential is applied to the electrodes, an electrical current is established through the conductive molten glass, thereby acting as a resistive heating element and introducing power to the meit to sustain operation.

The two different types of feeds require two different feeding techniques. A mechanism located in the lid of the melter known as a drop tube is lowered $10 \mathrm{~cm}$ into the melt during operation with combustible slurries. As the slurry is dried and combusted in the drop tube, the combustion gases are forced into contact with the molten glass thereby allowing mass transfer of radionuclides and particulates into the glass. This attains a high retention of radionuclides in the glass itself. This technique of feeding has been tested in an experimental-scale glass melter with a drop tube diameter of $3.8 \mathrm{~cm}$ at feed rates as high as $3 \mathrm{~kg} / \mathrm{h}$. The drop tube diameter of $86 \mathrm{~cm}(3.4 \mathrm{in}$.) presented in the MEVS conceptual design was scaled linearly with the diameter of the experimenta! melter's drop tube. This maintains identical residence times in the glass to achieve high retention values. The M:VS melter is capable of processing $70 \mathrm{~kg} / \mathrm{h}$ of resin slurries (which corresponds to the criteria in Table 2). Air cooling is provided at the bottom of the MEVS drop tube to maintain a viscous, relatively nonconductive layer between the drop tube and the molten glass to minimize the electrical shorting potential through the drop tube.

When feeding noncombustible slurries, the drop tube must be raised above the glass melt to allow cold cap formation. The drop tube is extracted from the melt via the air cylinder located on the lid of the melter to $10 \mathrm{~cm}$ above the glass Tevel. The overflow's air lift can reduce the glass level to attain additional separation between the bottom of the drop tube and glass, if necessary. The noncombustible slurry is premixed with glass frit in the mixing tank before being introduced to the surface of the glass melt. The heat from the glass pool evaporates the moisture and establishes a cold cap in which the glass formulation reactions take place. The nonvolatile waste constituents flux with the glass formers making a borosilicate glass composition.

Monofrax $\mathrm{K} 3$ is a registered trademark of the Carbiorundum Co. 
The process is not amenable to waste solutions with significant concentrations of sulfates (i.e., $<2 \%$ on a dry solids basis). Sulfate solubility in glass is limited to $0.5 \mathrm{wt} \%$. Incorporation of the MEVS process means that $\mathrm{Na}_{2} \mathrm{SO}_{4}$ regeneration solutions could not be processed. The resins could, however, be disposed directly in the melter instead of being regenerated.

Liquid feeding technology has been under development at PNL for greater than 10 years and has been selected as the prime alternative for feeding highlevel nuclear waste both in the United States as well as abroad. Numerous developrental melters have been tested at Pacific Northwest Laboratory and Savannah River Laboratory and presently PNL is undergoing the initial testing phase of a radioactive test melter using the liquid slurry feed technique.

The size of the melting cavity is based on the design basis criteria which states the minimum service requirements for various types of wastes. The melter as stated in the criteria can handle sludges, concentrated liquids or ion exchange resins from any three reactors whether they be boiling water reactors (BWR's) or pressurized water reactors (PWR's), with or without condensate polishing systems. For reactors that generate less than the maximum volumes of wet wastes shown in Table 2, the melter will service greater than the three reactor sites specified in the criteria. The melter cavity measures $1.37 \mathrm{~m} \times 1.67 \mathrm{~m} \times 0.41 \mathrm{~m}$ deep resulting in an exposed surface area of $2.3 \mathrm{~m}^{2}$. The maximum concentrated liquid rate which exists for a BWR with deep bed condensate polishing system results in a required rate of $210 \mathrm{~L} / \mathrm{h}$. At maximum production rates, this results in a minimum glass production rate of $200 \mathrm{~kg} / \mathrm{h}$ filling a canister of glass every 2 hours. These rates assume a $70 \%$ production factor with a 3-week shutdown period for transport and setup for each of three reactor sites as per the design basis criteria. The melter was designed for a $90 \mathrm{~L} / \mathrm{h} / \mathrm{hl}^{2} \mathrm{flux}$ rate. The rates demonstrated for high-level waste vitrification range from 30 to $100 \mathrm{~L} / \mathrm{h} / \mathrm{m}^{2}$; however, high-level wastes generally contain much more re"ractory components than is expected for low-level wastes (i.e., lowlevel waste contain little if any iron, zeolite, and other refractory components). Therefore the $90 \mathrm{~L} / \mathrm{h} / \mathrm{m}^{2}$ rate will be easily achievable for lowlevel wastes. 
The molten glass is contained within a composite of glass-contact and insulating refractory. It is important for a mobile system to reduce the overall mass of the melter, so a special design was incorporated to minimize the thickness of the glass-contact refractory, fused-cast Monofrax $3^{*}$, as well as the insulating backup refractories. To achieve this weight reduction, a water cooling jacket was employed around the melter shell. The cooling jacket removes the heat transferred through the refractory without dumping the heat load to the containment module. The heat in the cooling fluid is removed by a heat exchanger that is cooled by a recirculating giycol solution. This same glycol solution is used to remove the heat from the condenser and heat exchangers of the of $f$-gas effluent treatment system.

As molten glass is accumulated, it is drained through an overflow and poured by gravity into a receiving drum. The glass-pouring operation is controlled by an airlift in the riser of the overflow. The airlift can drain glass continuously or intermittently during operation or be used to drain $90 \%$ of the glass in the melter prior to transportation. The riser and the overflow are heated by an electrode and silicon carbide heating elements, respectively, to maintain fluidity of the glass while it is being poured.

The melter discharge spout on the overflow system connects to a sheet metal canister by means of a turntable assembly. The function of the turntable is to mate the receiving drum to the melter overflow chamber and relocate empty drums to the receiving station under the melter after filling in the same manner developed for remotely operable high-level waste melters. During filling, the drums are vented through the overflow chamber. After filling, the glass flow is intermittently stopped by the air lift control mechanism. A new drum is rotated into position and the filled drum is allowed to cool. A remotely operated crane then places the filled drum into an overpack through a bagless bagout port. The crane is also used to introduce a new drum from the airlock onto the turntable assembly. A remote monitor is used to observe these functions. This operational technique is adapted from remotely operable highlevel waste melters.

The bagless bagout port is specially designed to accept the filled drum into a standard overpack (i.e., a 55-gal drum) so as to eliminate the need for 
any external decontamination of the receiving container. The bagless bagout port prevents contamination of the overpack drum or its lid during loading. After the lid is resealed onto the overpack, the overpack drum is removed by a forklift and a new container is introduced. The system is designed so that no possibility of external contamination exists.

To restart the melter after shutdown, clean glass frit can be introduced and melted by an additional heat source through an open port in the meiter lid. The heat source is a plasma torch which is a small apparatus that can be attached externally to the melter lid. The plasma torch heats inert gases through an arc created in the torch. The radiant heat from these gases then preheat the glass frit in the melter to the point that electrical conduction in the glass frit is obtained. Melter power delivered through the electrodes completes the restart process.

Standard Equipment - Other than the melter, turntable, and bagless bagout device for the receiving drums, the remainder of the process is composed of standard equipment. The process flow diagram containing the process equipment is depicted in Figure 4. Beginning with the feed system, the combustible and noncombustible wet wastes are recirculated through a quick-clean, progressive cavity pump capable of pumping $250 \mathrm{~L} / \mathrm{h}$. This slurry pump has a variable speed to match the feed requirements to the melter. Pump speed is controlled by a control loop which maintains a desired level in the feed tank. The recirculating reed system is capable of pumping contaminated slurries and has the ability for air blowdown and line flushout.

The feed solution is directed at the appropriate feed rate to the feed and mixing tank. The mixing tank is equipped with an air displacement metering pump as well as an air sparger. In this tank, the glass formers are introduced to the "eed. It is important that the glass formers be well mixed with the feed especially when noncombustible slurries exist. The slurry of wet wastes and glass formers are then metered directly to the melter via the submerged, air displacement pump. The feed tank's size $(110 \mathrm{~L})$ is determined by the maximum column volume used for the the scrub solution decontamination system. 


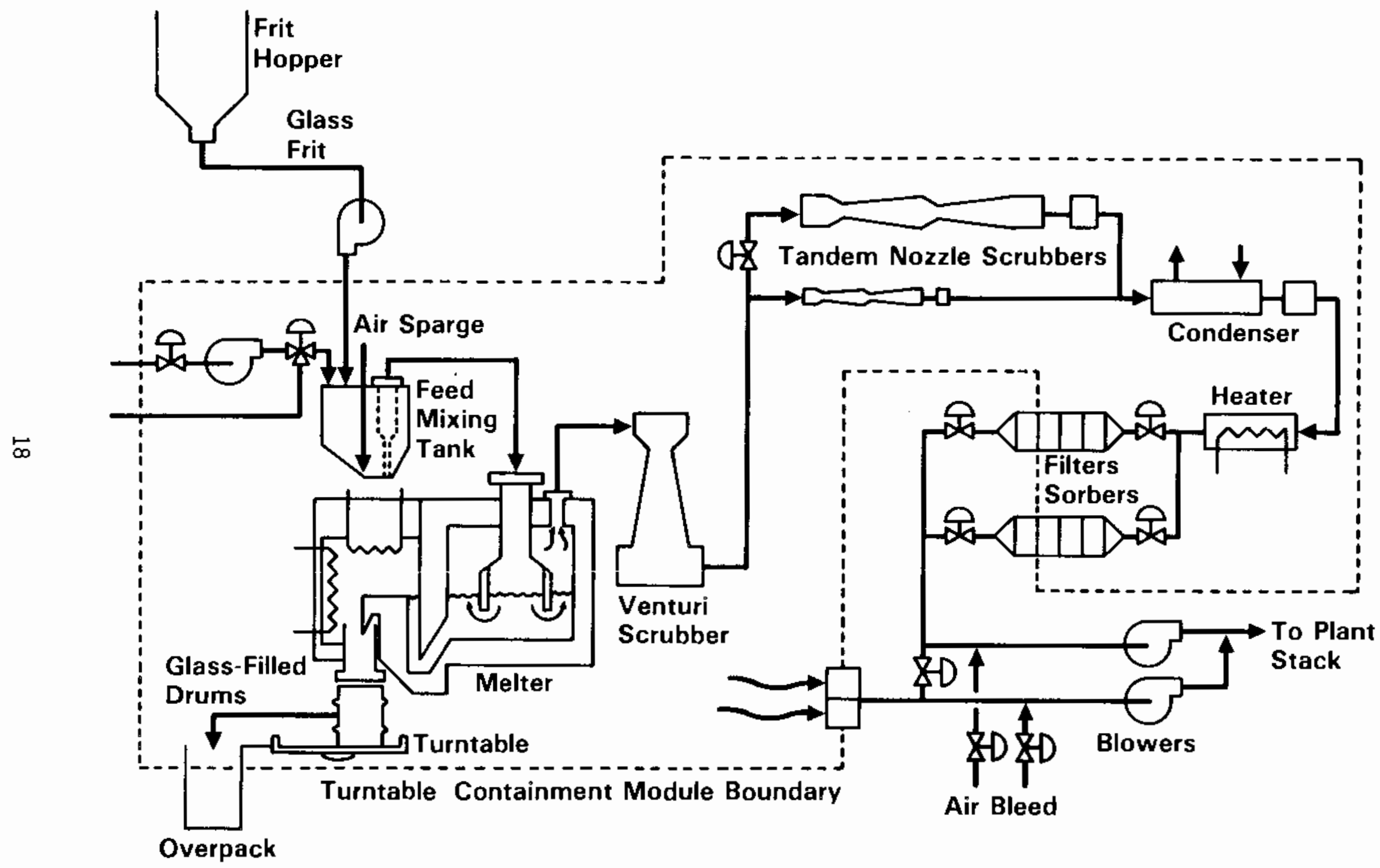

FIGURE 4. Process Flow Diagram 
The air displacement feed pump has been specially developed for high-level nuclear waste adaptations and has a long record of continuous operation requiring little maintenance. The rate at which the air driven pump delivers feed to the melter is selected manually by the operator through the computer control system.

When the gaseous effluents are discharged from the melter, they pass through a $15-\mathrm{cm}(6-\mathrm{in}$,$) nozzle in the melter 1 \mathrm{id}$. The exit region of this 15-cm of $f$-gas line is designed with a film cooler which greatly reduces the changes of plugging. This region has historically been an area where particulates have collected onto the wall of the off-gas line resulting in flaw restriction. The film cooler introduces high-flow, low-pressure air through baffles in the wall of the exit nozzle. The air is supplied by a high-pressure air source which passes through a vortex system converting to high-flow, lowpressure air. The film cooler maintains a boundary layer of clean air near the wall of the pipe allowing the particulate-loaded process effluents to pass through without plating to the exit nozzle. This device has a successful operating history in the melters developed for high-level nuclear waste vitrification.

From the exit nozzle, the process effluents are directed to the off-gas treatment system through a 30-cm (12-in.) off-gas line. The off-gas treatment system's designed to handle a range of flows as shown in the material schemat $c$, from a maximum of $33 \mathrm{STD} \mathrm{m}^{3} / \mathrm{min}(1170 \mathrm{scfm})$ to $3.2 \mathrm{sTD} \mathrm{m}^{3} / \mathrm{min}$ (110 scfm). The wide range of flows is required to accommodate the different types of feed and various design factors required in the design basis criteria. The des"gn factor for noncombustible slurries is eight times the nominal effluent rate; the design factor for combustible slurries is three times the nominal rate. These factors are based on processing behavior observed under past programs. Statistics indicate that an overpressurization of the melter under maximum conditions would occur no more than once per year. In the unlikely event of a pressurization of the melter, the melter is equipped with a recoverable pressure relief vent (a horizontally mounted swing check valve) that w' 1 exhaust the effluents to the containment module. These effluents will pass through the containment module filter system before being released to 
the adjoining reactor's heating, ventilating and air conditioning (HVAC) system. The containment module ventilation system is designed with identical design factors assumed for the off-gas treatment system.

The off gases are first introduced into a venturi scrubber whose purpose is to reduce the temperature of the gaseous effluents and provide initial scrubbing in the first stage. The overall decontamination factor (DF) of this unit is 10, removing most particulates greater than $2 \mu \mathrm{m}$. The venturi scrubber and associated off-gas line material prior to the venturi scrubber are composed of 321 or 347 stainless steel. This material contains stabilizers which tend to prevent carbide precipitation at temperatures greater than $450^{\circ} \mathrm{C}$, thus making the material resistant to stress corrosion cracking. The venturi scrubber is a $30-\mathrm{cm}(12-i n$.$) unit (inlet diameter) and is conducive to the wide$ range of off-gas flows expected from the melter.

After the venturi scrubber, the gaseous effluent flows are split into two tandem nozzle scrubbers. These scrubbers are highly effective for removing particulates as small as $0.5 \mathrm{~m}$ achieving DFs between 10 and 100 . The tandem nozzle scrubbers operate by two concentric sets of nozzles which deliver high volumes of scrub solution to the two throats of each scrubber. This creates a high pressure drop for efficient scrubbing action. Because the high pressure drop can only be obtained for a narrow range of flows, two scrubbers of different sizes were selected for the MEVS process to accomodate the wide range of off-gas flows expected with this system. Following scrubbing in the tandem nozzle scrubbers, the process effluents are separated from the entrained scrub solution in two vane separators, one for eacli tandem nozzle scrubber. The separator impinges the droplets onto baffle plates which drain the scrub solution to the scrub tank. The scrub solution is drained to the scrub tank through two heat exchangers which are cooled by a closed-10op glycol cooling system. These remove the heat in the scrub solution absorbed from cooling and condensing the process effluent stream. The scrub solution flow diagram is shown in Figure 5 .

Two independently operated pumps provide scrub solution to the venturi and tandem nozzle scrubbers. The two pumps are self priming and provide a multitude of other services such as tank recirculation, scrub solution purge 


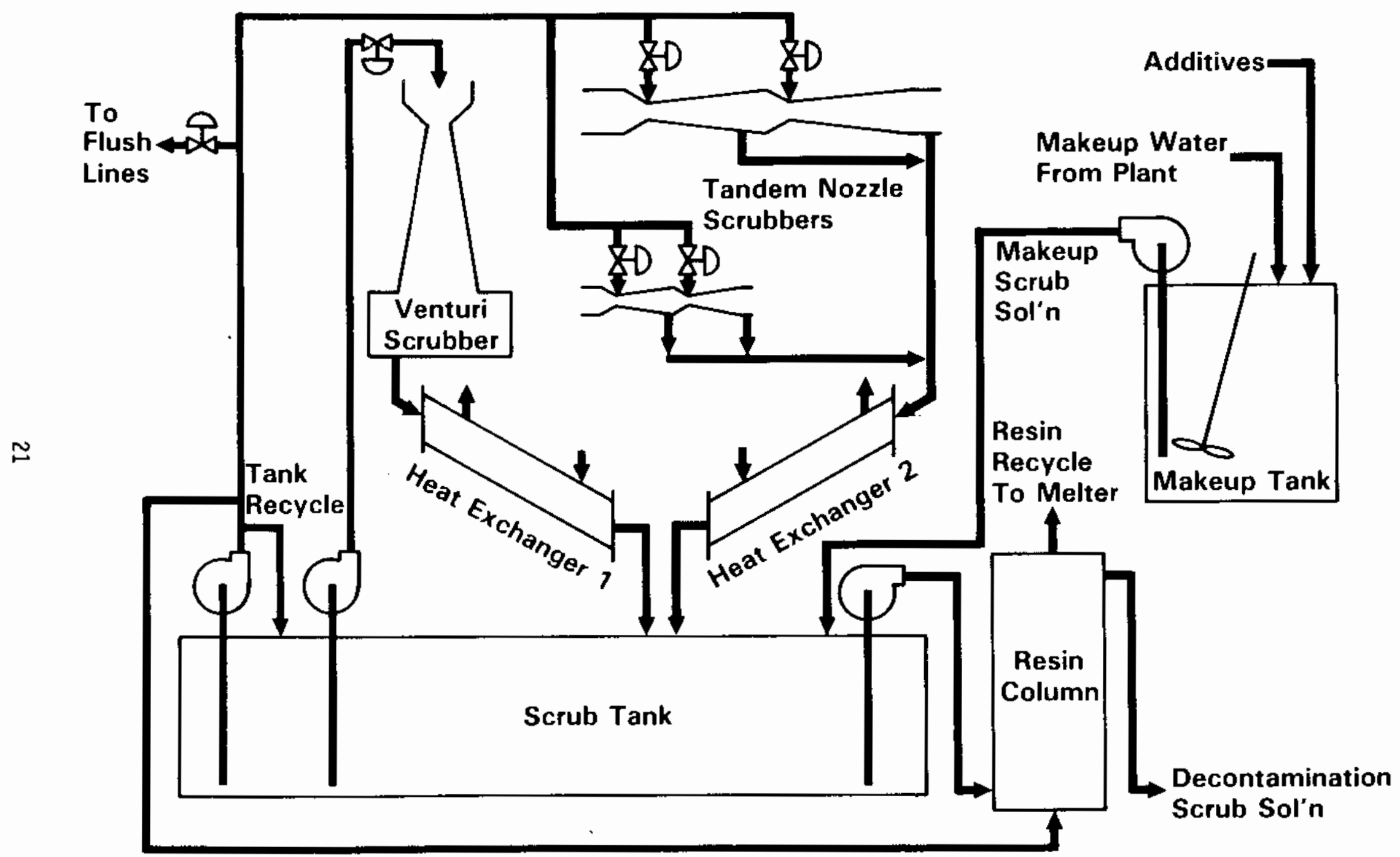

FIGURE 5. Scrub Solution Flow Diagram 
through the scrub decontamination system, and decontamination of the internal process equipment and piping. The scrub decontamination system consists of a series of resin columns (zeolite and organic resirs) through which the scrub solution is purged and recycled back to the plant at <1 ppm total organic carbon (TOC) and <1 wnho conductivity.

Downstream of the scrub system, the process effluent streams are recombined at the condenser and final vane separator. These items provide an additional DF of 100 by cooling the off gas and removing entrained droplets. The condenser heat load is removed by the same recirculating glycol system that cools the scrub solution.

Following the final vane separator, the off gases pass through a heater prior to filtration. The heater prevents condensation from collecting in the filters or iodine adsorbers. The heater, which is controlled by the distributed process control system, uses a temperature sensor on the exhaust of the heater for control as well as an overtemperature snutdown circuit to protect the heating elements.

Following reheating of the effluent stream, the gases are then directed through a primary stage HEPA filter and iodine adsorber system. The iodine adsorber rests between primary and secondary HEPA filter banks. The adsorber is designed to meet Nuclear Regulatory Commission (NRC) regulatory standards of a 0.5 s contact time. At this point, the off gases are considered to be decontaminated. The iodine adsorber and filters have a redundant backup assembly. The redundant system is provided in the event of failure or changeout due to excessive loading. Each bank of filters provides a DF of $10^{3}$ for 0.3 um particulates, for a combined theoretical of of $10^{6}$. However experience with similar process systems shows no accumulation on the second stage filter. It serves as an in-line backup should the primary system fail. Therefore the overall filter $D F$ is considered to be only $10^{3}$.

The driving force that draws the process effluents from the melter through the off-gas system is an induced draft blower system. Each of two blowers are capable of producing $57 \mathrm{~m}^{3} / \mathrm{min}(2,000 \mathrm{cfm})$ at $90^{\circ} \mathrm{C}$ and $230 \mathrm{~cm}(90 \mathrm{in}$ ) of water negative pressure ( $\left.33 \mathrm{STD} \mathrm{m}^{3} / \mathrm{min}\right)$. One blower is dedicated to ventilating the 
containment module and the other is dedicated to the off-gas system. Each of these blowers can serve as a backup to the other in the event of failure.

The off-gases are exhausted from the blower discharge for a combined maximum flow of $90 \mathrm{~m}^{3} / \mathrm{min}$ at $100^{\circ} \mathrm{C}$ and atmospheric pressure (66 STD $\mathrm{m}^{3} / \mathrm{min}^{\mathrm{n}}$ ). The concentrations of radionuclides at the stack are well within Table 2 limits defined in 10 CFR 20 (Code of Federal Regulations). The concentration of any one radionuclide at the MEVS stack during normal operation prior to being exhausted to the plant stack is $1.5 \times 10^{-12} \mathrm{\mu Ci} / \mathrm{ml}$. These are based on a conservative $D F$ value of 10 at the melter and using conservative $D F$ values described in the text for the off gas system components. The respective Table 2 limits for ${ }^{137} \mathrm{Cs},{ }^{90} \mathrm{Sr}$, and ${ }^{60} \mathrm{Co}$ are $2 \times 10^{-9}, 3 \times 10^{-11}$, and $1 \times$ $10^{-8} \mathrm{\mu} \mathrm{i} / \mathrm{ml}$ for soluble components and $5 \times 10^{-10}, 2 \times 10^{-10}$, and $3 \times$ $10^{-10} \mu \mathrm{Ci} / \mathrm{m}$ l for insoluble components. Because of the redundancy employed in the design (i.e., backup filters and blowers), the loss of any single component will not result in exceeding the Table 2 concentration criteria thus meeting the requirements of the design basis criteria. A "failure mode and effects" analysis of the process will be performed during conceptual design activities to further assure releases will be kept within facility requirements. 
. 


\section{COST ESTIMATE AND SYSTEMS ANALYSIS}

The preconceptual design of the MEVS provided the basis for a capital and operating cost estimate for the process. The total estimated cost for the process is $\$ 4,680,00$. The annual operating cost to process combustible slurries (i.e., resins and combustible filter sludges) is $\$ 1,530,000 / y r$, or if used to process noncombustible slurries (i.e. concentrated liquids and noncombustible filter sludges), the operating cost is $\$ 2,280,000 / y r$. Together with the production rates for each type of waste, the costs are utilized to determine the total disposal costs on a waste volume basis for comparative purposes.

\section{CAPITAL COST ESTIMATE}

The capital cost estimate, prepared by Kaiser Engineers Hanford Company (KEH), includes all labor and materials required to design, procure, fabricate, inspect and license the MEVS process. All procurement and fabrication items are assumed to be fixed-price competitive procurements. They include a $26 \%$ contingency and an $8.6 \%$ escalation factor so that the costs represent a January 1987 completion date. Engineering and inspection services comprise of $30 \%$ of the construction costs, based on past experience by PNL and KEH. These costs are also provided with escalation and contingency factors. When comparing the estimated capital cost with those for other processes, one must carefully observe which factors are included. The combined procurement and fabrication cost for MEVS is $\$ 2,670,000$. However, when accounting for escalation, contingency, engineering and inspection services, and licensing activities, the tota? cost is $\$ 4,680,000$.

The capital cost estimate does not include the verification testing necessary :0 support definitive design of the MEVS. Verification testing is necessary "o confirm melter and drop tube scaleup data with simulated low-level waste formulations. It is assumed one of the Department of Energy's existing melters at PNL would be available for verification testing to keep these costs to a minimum. The verification testing costs are not expected to exceed 
$\$ 770,000$. Verification testing may provide enough processing experience to improve the productions rate of the MEVS, which would reduce operating costs.

OPERATING COST ESTIMATE

The breakdown for the operating cost estimate is given in Appendix $B$. Separate operating costs are given for combustible and noncombustible slurries. The system processes combustible slurries at a lower rate than noncombustible concentrated liquids, so fewer costs are incurred for glass containers and glass formers. Also, combustible feeds provide much of their own heat for melting so electrical energy requirements are reduced. The costs in January 1985 dollars are $\$ 2,280,000 / y r$ for noncombustible slurries (concentrated liquids) and $\$ 1,530,000 / y r$ for combustible slurries (resins).

The operating cost estimate used a conservative estimating approach to ensure that all actual costs will have been covered in the estimate. The process is assumed to be continuously monitored by two fulltime operators in an "ABCD" shift schedule. A dedicated radiation protection technician is also assumed to be necessary 24 hours per day. The estimate allows for a day shift supervisory engineer, a transport crew, and staff for routine maintenance. A travel allowance is also assumed. In addition, a significant allowance is made for nonroutine maintenance (materials and labor). This allowance replaces processing equipment at the completion of their useful life. The allowance is based on $33 \%$ of the capital investment of the meltar, which requires replacement every three years, and $10 \%$ of the remaining capital items, which have a minimum 10-yr operating life. The nonroutine maintenance factor should not be confused with capital recovery. The factor simply keeps the system new. With the nonroutine maintenance factor, the entire system can be expected to be competitive with the longest term solidification systems (i.e., 30 yrs).

SYSTEMS ANALYSIS

The best comparison of costs of the MEVS with practices presently employed is to compare the entire "cradle to grave" disposal costs. In addition to producing a geologically stable waste form, MEVS significantly reduces the volume of the waste to be destroyed. All moisture is driven from the waste and 
recycled back to the plant. Combustible portions are destroyed in the melter and the combustion effluents are scrubbed and exhausted through the plant stack. Only the radionuclides and nonvolatile portions are vitrified with silica and alkaline glass formers into a glass product of reduced volume. Volume reduction significantly reduces the transportation and burial costs, which not only offsets the processing costs but justifies the volume reduction process on an economic basis.

The most common form of disposal presently employed is to concentrate the wet wasties by evaporation and solidify the concentrated liquids, resins, and sludges by cementation. The cemented wastes are deposited in 55-gal drums or liners capable of holding $5.4 \mathrm{~m}^{3}\left(190 \mathrm{ft}^{3}\right)$. The cementation process actually increases the evaporated waste volume by a factor of 1.3 , which increases the transportation and disposal cost. Total disposal costs from the evaporator through burial have been quoted by plant operators from $\$ 155 / \mathrm{ft}^{3}$ to $\$ 350 / \mathrm{ft}^{3}$ for concentrated 1 iquids and from $\$ 300$ to $\$ 350 / \mathrm{ft}^{3}$ for resin siurries.

A comparison of disposal costs for cementation and MEVS is given in Table 1 in dollars per cubic ft of wet wastes before solidification. The MEVS operations costs are derived from the annual operating cost divided by the annual waste processing volume. The MEVS processing costs also include an allowance for full capital recovery and a $20 \%$ rate of return on investment. The cos:s of processing and cask rental for cementation have been quoted by plant operators. Cask rental for vitrification is assumed to be identical on a volumet-ic basis for solidified waste. The remaining costs for burial and transpontation are presented by Jacobs et al. (1984). They report annual costs for each category by cementation of $360 \mathrm{~m}^{3}\left(12,700 \mathrm{ft}^{3}\right)$ of concentrated liquids in January 1983 dollars. The costs have been escalated to January 1985 for an accurate comparison. The only discrepancy exists with processing and cask rental zosts. For these two categories the verbally quoted prices were used in this comparison. The radiation and curie surcharges reported by Jacobs are factored linearly for cementation to comply with the radionuclide concentrations specified in the design basis criteria. The radiation surcharges for MEVS are reduced because of the self-shielding obtained by the increased density of the glass waste form. 
TABLE 1. A Comparison of Disposal Costs for Cementation and MEVS $\left(\$ / \mathrm{ft}^{3}-\mathrm{Jan} 1985\right)$

Cementation
(Resins or
Conc. Liquits) Resins Conc.Liq.

Processing

- Operations

121

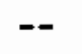
on investment

Transportation

- Transport, truck rental, and loading

- Cask renta 1

Disposa?

- Burial

- Radiation surcharge

- Curie surcharge

- Weight surcharge

- Perpetuity escrow fund

- Disposal and business 1 icense tax

$\begin{array}{ccc}24 & 2 & 8 \\ 9 & 4 & 4 \\ 13 & 13 & 13 \\ 9 & 1 & 3 \\ 4 & <1 & 1 \\ \frac{9}{\$ 295 / \mathrm{ft}^{3}} & \frac{1}{\$ 218 / \mathrm{ft}^{3}} & \frac{3}{\$ 191 / \mathrm{ft}^{3}}\end{array}$

MEVS costs per $\mathrm{ft}^{3}$ are lower for transportation and burial because of the volume reduction factor. Fewer casks are needed and less volume at the burial site is required. The analysis assures one cask per shipment and that $5.4 \mathrm{~m}^{3}$ (190 $\mathrm{ft}^{3}$ ) of cement can be stored in each cask. However only 14 drums of glass can be transported in one cask, each containing $0 . .6 \mathrm{~m}^{3}\left(5.7 \mathrm{ft}^{3}\right)$ of glass (75\% full) for a total of $2.3 \mathrm{~m}^{3}\left(80 \mathrm{ft}^{3}\right)$. Nevertheless, because of the volume reduction factor, cost savings are realized for cask rental. Cost savings are more pronounced for the remaining disposal costs.

Escalation plays an important factor in determining the merits of MEVS. Jacob et al. (1984) have conducted an analysis of processing, transportation, and burial costs over the last 10 years. They've cletermined that processing, transportation, and burial costs will escalate at $6 \%, 9 \%$, and $15 \%$ respectively in the future. Incidentally, burial costs from Jaruary, 1975 to October, 1982 
have escalated at an alarming $38 \%$ per year rate, so the $15 \%$ assumed rate may be conservative. The difference in escalation rates makes high volume reduction processes even more attractive in the future. The MEVS provides an extremely high volume reduction with only a small portion of the total cost being burial costs. Burial costs are $1 / 3$ and $1 / 2$ of the cementation disposal costs for resins and concentrated liquids respectively. The difference in escalation will result in total disposal costs in January 1995 as shown in Table 2 . The differences in burial and transportation costs are even more pronounced.

Using the comparison in Table 1, and knowing the process capability of MEVS is $360 \mathrm{~m}^{3} / \mathrm{yr}\left(12,700 \mathrm{ft}^{3} / \mathrm{yr}\right)$ for resins and $1080 \mathrm{~m}^{3} / \mathrm{yr}\left(38,100 \mathrm{ft}^{3} / \mathrm{yr}\right)$ for concentrated liquids, the capital investment can be recovered in a short period of time. At a compensation rate equivalent to cement $\left(\$ 300 / \mathrm{ft}^{3}\right)$, the capital investment could be recovered in two years for processing resins or less than one year for concentrated liquids. This should provide adequate incentive for private industry and utilities to consider MEVS.

Other economic comparisons of MEVS with solidification processes are available. Since other volume reduction process are rare and have little operating history, no actual operating costs for comparative systems are available. However, Jacobs et al, have generated cost estimates for not only cementation, but for alternative volume reduction bases as well. It is important to compare the different processes under equivalent bases. As noted previously, discrepancies exist between Jacobs et al. and quoted costs from plant operators for cementation processing and cask rental. Jacobs et al. used much lower labor rates and material costs than assumed in the MEVS operating cost estimate. In addition, no allowance was made for nonroutine maintenance. By equilibrating the assumptions for processing costs and cask rental, the comparison shown in Table 2 with alternative processes can be made. The MEVS processing costs still includes the same number of operators. Equivalent labor rates, lowever, have been assumed. The MEVS cost estimate stili includes the cost necessary to replace the melter every three years but does not include other nonroutine maintenance items, because none are allowed in Jacobs et a?. estimatas. The costs in Table 3 are shown in 1983 dollars as reported by Jacobs st al. 
TABLE 2. A Comparison of Disposal Costs for Cementation and MEVS January $1995\left(\$ / \mathrm{ft}^{3}\right)$

Escalation Rates

Processing - 6\%

Transport - 9\%

Disposal - 15\%

Cementation

Resins and Conc. Liq. Tesins Conc. Liq.

Processing

217

320

152

Transportation

251

43

175

Disposal

Total

299

767

$\frac{85}{448} \quad \frac{129}{456}$

TABLE 3. Disposal Costs Using Assumptions by Jacobs et al. (1984) in January 1983 Dollars $\left(\$ / \mathrm{ft}^{3}\right)$

\begin{tabular}{|c|c|c|c|}
\hline \multicolumn{4}{|c|}{ Concentrated Liquids $\left(\$ / \mathrm{ft}^{3}\right)$} \\
\hline Cementation & $\begin{array}{l}\text { Crystallizer } \\
\text { \& Cementation }\end{array}$ & $\begin{array}{c}\text { Asphalt } \\
\text { Stabilization }\end{array}$ & MEVS \\
\hline 11 & 6 & 8 & 20 \\
\hline 31 & 12 & 11 & 9 \\
\hline 63 & 26 & 24 & 20 \\
\hline 105 & 44 & 43 & 49 \\
\hline
\end{tabular}

Processing

\begin{tabular}{|c|c|c|}
\hline \multicolumn{3}{|c|}{ Resins $\left(\$ / \mathrm{ft}^{3}\right)$} \\
\hline Cementation & Dewatering & MEVS \\
\hline 11 & 55 & 62 \\
\hline 31 & 24 & 3 \\
\hline 76 & 60 & 7 \\
\hline 118 & 139 & 72 \\
\hline
\end{tabular}


The table shows that even under the optimistic cost estimate approach presented by Jacobs, that MEVS is competitive if not advantageous to other technologies. The MEVS process has the distinct advantage, however, of producing glass, a geologically stable waste form over the long term. For combustible slurries, MEVS has a relatively high volume reduction compared to other processes. Under high escalating conditions, this fact will make the process even more attractive in the future. 


\section{DEVELOPMENTAL REQUIREMENTS}

MEVS technology closely resembles vitrification technology that was selected as the primary treatment process for high-level wastes in the United States. However, some nonradioactive testing is needed to understand the effect of the differences between high-level and low-level waste compositions on MEVS operation. The testing is also needed to verify that anticipated modifications to the melter will accommodate combustible low-level wastes on a larger scale. These studies would take the form of four 5-day pilot-scale runs with an existing melter, modified for low-level waste vitrification. The four runs would be conducted with a range of feed formulations to verify processing performance characteristics. Key process variables to be verified would be process rate, radionuciide retention in the glass, and processing stability. In support of these tests, glass formulation checks would be run in the laboratory and in an existing experimental-scale melter. The verification program could be conducted at PNL for $\$ 770 \mathrm{~K}$ over a 9-month period. 


\section{UTILITY ASSESSMENT}

One of the objectives of this program is to obtain an assessment of utility interests in the volume reduction service that MEVS provides.

Written expressions of interest in utilizing the process were actively solicited from utility representatives. The following is a list of personnel and utiities contacted during the assessment:

G. Dean Weyman - Vermont Yankee Nuclear Power Corporation

Mark S. Strum - Yankee Atomic Electric Company

G. Jonathan Moffitt, Jr. - Philadelphia Electric Company

Robert J. Scholz - Philadelphia Electric Company

Koneta E. Przeworski - Philadelphia Electric Company

Mary Hyslop - Philadelphia Electric Company

George Warner - Carolina Power and Light

Pete Mays - Carolina Power and Light

Roy Jongebloed - Long Island Lighting Company

Ezekiel B. Sachs - Long Island Lighting Company

Charles Bosch - Long Island Lighting Company

The utility assessment provided some very encouraging findings on how the utilities perceive the adaptability of the MEVS to their present and near-term plans for radioactive waste disposal. There appears to be a great deal of uncertainty as to the status of the national disposal sites after January 1 , 1986. According the Low-Level Radioactive Waste Policy Act of 1980, individual states will assume responsibility for wastes generated within its borders (Moore :-985). States currently operating national waste disposal sites may close them or put severe restrictions on acceptance of wastes at that time. Present indications are that the national sites may remain open for another four yecrs. Nevertheless, increased emphasis is placed on volume reduction for on-site storage should the sites close, or for disposal at national sites due to increasing burial costs.

Utility representatives were most impressed by the transportable selfreliant process approach. They do not appear to be willing to commit capital dollars or hire more operating staff for radwaste treatment at this time. 
Contracted services for radwaste treatment greatly appeals to the radwaste managers. It allows them flexibility, an essential for adapting radwaste volume reduction processes to the utilities at this time.

Another desirable feature of the process that appealed to the utilities was the self-contained approach requiring minimal interfaces and services from the nuclear plant. The diesel generators, which provide operating and backup power for the melter and off-gas system, met with good response. Most utilities do not have spare $1200 \mathrm{~A}, 480 \mathrm{~V}$ buses to operate the system.

Cleanup of the off gases prior to release was also an essential for acceptance. The off-gas system gives the utilities the flexibility to exhaust directly from the process trailer or to tie in with the plant stack to maintain a single exhaust point on the plant site.

During the utility assessment, it became apparent that the assumption that ion exchange resins can be fed to the melter as a pumpable slurry needs to be reevaluated. Most resins are currently dewatered. It is more sensible to feed the resins to the melter as a wet solid than to resiurry the resins, which would create additional condensate. The glass former feeder located on the top of the process trailer could be adapted to feed wet solids.

Another process attribute that needs to be reconsidered is the disposal of the condensate produced from the vitrification of wet wastes. The preconceptual design calls for a resin column to decontaminate the condensate of radionuclides prior to disposal. The resins can then be recycled to the melter for full incorporation of radionuclides. However, the presence of sulfanate groups in ion exchange resins will produce a dilute sulfate/sulfite scrub solution. It is unknown what the sulfur concentration will be or whether it will impact the removal efficiency of the resin column. The uncertainty lies in the degree of solubility of sulfates in the glass, which is normally limited to 0.5 to 1.0 wt\%. As discussed previously, verification tests are necessary to answer technical questions such as these and provide information for definitive design. Also, the acceptable release concentrations of sulfates for chenical waste disposal at a reactor facility needs to be investigated. 
Overall, the response of the utility representatives was quite positive. They are not satisfied with the present state of commerically available technology for radwaste volume reduction and stabilization. The costs presented for the MEVS service, in most cases provided an economic incentive for the MEVS. The overall response of the utilities was if the expected costs reported are true, then indeed the MEVS will fill the low-level waste treatment needs and should be supported for commercial development. 


\section{REFERENCES}

Bjorklund, W. J. and R. A. Brouns. 1982. Operating Characteristics of a Direct Liquid-Fed Vitrification Process. PNL-SA-9811, Proceedings on the Treatment and Handing of Radioactive Wastes, Richland, Washington.

Buelt, J. L. 1982. A Vitrification Process for the Volume Reduction and Stabilization of Organic Resins. GEND-023, National Technical Information Service, Springfield, Virginia.

Code of Federal Regulations. 10 CFR Part 20 App B, Washington, 0.C.

Jacobs, M. H., et al. 1984. Low Level Radwaste Engineering Economics. EPRI-NP-3577, Electric Power Research Institute, Palo Alto, California.

Klingler, L. and K. Armstrong. 1984. "Application of Joule-Heated Glass Furnace to Hazardous Waste Treatment." In: Proceedings of the Second Annual Hazardous Materials Management Conference, Philadelphia, Pennsylvania.

Moore, T. 1985. "The Great State of Uncertainty in Low-Level Waste Disposal." EPRI Journal. March 1985, Vol. 10, No. 2, pp. 22-29. 
APPENDIX A

DESIGN BASIS CRITERIA 


\section{DESIGN BASIS CRITERIA}

Design basis criteria have been established for the MEVS by PNL with collaboration by Nuclear Energy Services (NES). These criteria formulate the guidelines for the system design in order to assure that the MEVS will perform satisfactorily and efficiently at any nuclear reactor site. The criteria reflect the objectives for the MEVS in terms of throughput rates, wet waste streams characteristics, regulatory requirements and compliance, operability of the process, life expectancy of the equipment, and safety considerations. The Design Basis Criteria are prepared strictly for the purpose of developing the conceptual Design and the Performance (Economical) Evaluations. Thus, the Design Basis Criteria will not provide a narrative design or detailed design criteria.

The Design Basis Criteria are formatted after the PNL Construction Project Management Manual (PNL-MA-91), which serves as a guideline for construction projects under the direction of PNL. Conformance with the design criteria format does not imply, however, that this study meets all other requirements for a line item project. Presently the design criteria categories include:

- General requirements

- Functional requirements

- Process

- Structural

- Mechanical

- Electrical

- Occupational/Environmental safety

- Security

- Quality assurance

GENERAL REQUI REMENTS

The general requirements of the Design Basis Criteria identify the codes, standards, and other regulatory requirements that are fundamentally applicable 
to the design of the MEVS. The preconceptual design is prepared considering the self-sufficiency performance of the MEVS at a serviced reactor site. Potential radiological consequences will be evaluated as the design proceeds and compared with the release limits stipulated in Column 2, Table II, Appendix $B$ of 10 CFR Part 20. This evaluation will determine the reliability and any redundancy requirements to be reflected in the preconceptual design.

A11 piping, pressure vesse1s, tanks, and processing equipment containing gaseous or 1 iquid radioactive streams must be designed in accordance with NRC Regulatory Guide 1.143. Table A.1 delineates the applicable codes to which the design of various components must perform as cited in Regulatory Guide 1.143 .

$\begin{aligned} & \text { TABLE A-1. } \\ & \begin{array}{l}\text { Equipment Codes for Preconceptual Design } \\ \text { (Compiled from Table } 1 \text { of NRC Regulatory } \\ \text { Guide 1.143, Design and Fabrication Codes) }\end{array} \\ & \text { Pressure vessels } \\ & \text { ASME Code Section VIII. Div. 1 } \\ & \text { ASME Code Section III. Class 3, } \\ & \text { Or API 650, or AWWA D-100, or } \\ & \text { API 620 }\end{aligned}$
$\begin{aligned} & \text { Heat exchangers } \\ & \text { ASME Code Section VIII. Div. 1 }\end{aligned}$
$\begin{aligned} & \text { Piping and valves } \\ & \text { ANSI/ASME B31.1 } \\ & \text { Electrical }\end{aligned}$

FUNCTIONAL REQUIREMENTS

The functional requirements of the design criteria include the requirements which identify the capacity and type of waste to be vitrified with the MEVS. Functional requirements also provide the operating system requirenents and architectural and structural criteria which identify the number of transportable units to be used and the criteria relating to their physical arrangeinent. In addition, the functional requirements identify the mechanical piping and ventilation requirements for the transportable system as well as fire protection requirements. Also included are requirements for electrical systems, both power and lighting, communications systems, and instrumentation and process control. 
PROCESS REQUIREMENTS

When designing the melter system, the existing technical data base developed at PNL and elsewhere for high-level waste vitrification with jouleheated glass melters, as well as the technical data base developed for the vitrification of ion exchange resins, are to be used. In determining the appropriate internal dimensions of the melter, a $70 \%$ of full production rate is to be assumed as the average production rate of the melter. A three-week period is allotted for shutdown, travel between reactor sites, and a restartup of the melter between campaigns. The melter is to be designed to conform to the size requirements stipulated in the Architectural/Structural Requirements and to process wet wastes generated from commercial nuclear reactors in the form of spent ion exchange resins, concentrated liquids, and filter sludges. This process is to be designed to vitrify the spent ion exchange resins from a minimum of three 1,000 MWe BWRs equipped with the deep-bed condensate polishing system with annual spent resin volume of approximately $4,600 \mathrm{ft}^{3} / \mathrm{y} / 1,000 \mathrm{MWe}$. The MEVS must be designed to process an equivalent amount of either of the other two types of wet waste (concentrated liquids or filter sludges) from a minimum of three reactors, whether they be BWRs or PWRs, either with or without deep-bed condensate polishing systems (C.P.S.) This means that al though the design basis is selected on the quantity of organic combustible spent resins, the melter is to be designed to also handle slurries of concentrated liquids (evaporator bottoms and decontamination solutions) and filter sludges. The melter should be adapted to feeding each of these wastes independently of the design rate or simultaneously at a correspondingly reduced rate. Table A.2 gives the annual volumes of the equivalent types of wet waste to be vitrified for each 1,000 Mwe plant. The table has been reduced from information developed in the EPRI Low-Level Waste Project, Study EPRI-1557-13, which gives average annual generation rates of these waste types for various reactor systems. The process is not to be designed, however, to vitrify resin regeneration solutions or other slurries that would result in a glass composition $>0.5$ wto sulfates. 
TABLE A.2. Annual Generation Rates and Curie Inventories for 1,000 HWe Reactors (BWR/PWR)

\begin{tabular}{|c|c|c|c|}
\hline & $\begin{array}{c}\text { Ion Exchange } \\
\text { Resins } \\
\end{array}$ & $\begin{array}{l}\text { Concentrated } \\
\text { Liquids } \\
\end{array}$ & $\begin{array}{l}\text { Filter } \\
\text { Sludge }\end{array}$ \\
\hline BWR with deep bed C.P.S. & $\begin{array}{l}4,600 \mathrm{ft}^{3} \\
990 \mathrm{cj}\end{array}$ & $\begin{array}{l}12,700 \mathrm{ft}^{3} \\
150 \mathrm{Ci}\end{array}$ & $\begin{array}{l}5,400 \mathrm{ft}^{3} \\
1,200 \mathrm{Ci}\end{array}$ \\
\hline BWR with percent C.P.S. & $\begin{array}{l}229 \mathrm{ft}^{3} \\
50 \mathrm{ci}\end{array}$ & $\begin{array}{l}600 \mathrm{ft}^{3} \\
7.1 \mathrm{Ci}\end{array}$ & $\begin{array}{l}7,700 \mathrm{ft}^{3} \\
1,700 \mathrm{Ci}\end{array}$ \\
\hline PWR with C.P.S. & $\begin{array}{l}321 \mathrm{ft}^{3} \\
0.53 \mathrm{Ci}\end{array}$ & $\begin{array}{l}4,800 \mathrm{ft}^{3} \\
22 \mathrm{Ci}\end{array}$ & $\begin{array}{l}141 \mathrm{ft}^{3} \\
5.7 \mathrm{Ci}\end{array}$ \\
\hline PWR wi thout C.P.S. & $\begin{array}{l}939 \mathrm{ft}^{3} \\
1.6 \mathrm{Ci}\end{array}$ & $\begin{array}{l}3,900 \mathrm{ft}^{3} \\
18 \mathrm{Ci}\end{array}$ & -- \\
\hline
\end{tabular}

The process is to be designed to provide maximum volume reduction for the resins, sludges, and concentration liquids. Ideally, volume reductions, relative to the untreated volume of wet waste fed to the process, of 100 for organic resins, 10 for inorganic sludges, and 10 for concentrated liquids should be achieved. However, practical limitations indicate that a minimum volume reduction to which the design is to be established should be 10 for combustible ion exchange resins and sludges and a factor of 2.5 for noncombustible sludges and concentrated liquids (i.e., evaporator bottoms). Volume reduction limitations are governed by a number of $i$ tems.

1. Volume reduction of inorganic components of the waste stream make up a part of the glass material, which has a density range of 2.4 to 3.0. Since the inorganic constituents must be supplemented with glass-forming chemicals to achieve the appropriate glass formulation, the volume reduction for inorganic slurries is influenced by the amount of water in the waste stream and the density difference between the feed stock and glass product.

2. Although the combustion of organic resins produce very little inorganic material, their minimum volume reduction requirement is limited to that demonstrated in previous developmental tests. Volume reductions in excess of 10 for organic resins might create higher alkaline radioactive element concentrations, e.g., cesium and 
strontium, in the glass than can be accommodated. Since the retention of semi-volatile radionuclides such as cesium is thought to be a mass transfer process from the gaseous phase to the molten liquid phase, a higher-than-demonstrated cesium concentration in the glass could reduce the mass transfer driving force (a concentration gradient between the combustion gas and the molten glass). This could result in a loss of retention of radionuclides in the glass, thus limiting the volume reduction to previous demonstration values (i.e., 10).

3. Some ion exchange resins contain alkaline or alkaline-earth activation groups which are incorporated into the glass and can affect the molten glass properties when influenced by more than a few weight percent of these elements. However, because the relative amount of alkaline and alkaline-earth elements associated with the resins is sma11, this effect is not expected to seriously affect the molten glass properties.

Another process requirement is minimizing gaseous and liquid effluents from the process. To minimize gaseous effluents, yet ensure complete combustion, existing test data shows that the oxygen concentration in the combustion gas for combustible feeds is to be designed for an average of $15 \%$ with an acceptable range between $8-21 \%$. The melter and connecting off-gas and feed systems are to be designed so that the inleakage rate is no greater than 20 SCFN at 15 inches of water melter plenum vacuum. The gaseous effluents are to be scrubbed and filtered so that discharge to the MEVS's ventilation system meets with criteria identified in the General Requirements (Table II of 10 CFR 20). Liquid effluents, i.e., scrub solutions from the wet scrubbing system, are to be cleaned to within the guidelines stated in the General Requirements. The system must be designed so that the discharge of the liquid effluents can be sampled and surveyed prior to leaving the confines of the processing trailer.

The process is to be provided with restart capability in two modes. The restart system must remelt glass in the melter that has been solidified due to an emergency shutdown (i.e., loss of power), and it must also restart an empty 
melter while feeding clean glass frit at the beginning of a campaign. Provision for standby heating to avoid thermal shock should also be made. The process unit is to be designed to function with a minimum of unprocessed waste in the unit. Provisions for back flushing and decontaminating process waste equipment and piping should be made. A minimum curie inventory should be retained in the glass heel of the melter during transport.

The feedstock should be recirculated through the feed system eliminating tankage of the feed material in the trailer(s). The glass melter should be able to be drained to a minimum of $10 \%$ of full volume to reduce the inventory during transport. A product handling area is to be included to package and transfer the glass product out of the transportable processing system shortly after a canister is filled and cooled. Although an accumulation of waste is allowed in the wet off-gas scrub tank, the system must be designed with a continuous or batch-type purge through a decontamination system to remove these radionuclides. The solid residue from the decontamination system must then be able to be transferred out of the transportable system or directly recycled to the glass melter.

The transportable system is to be designed without reliance on reactor operator staff. The transportable process is to be designed for operation by a maximum number of two technical operators plus the appropriate number of radiation protection technicians and supervisors. The functions of the operators include:

1. Supervisory and control functions of the process including feed, offgas, and melting operations.

2. Waste product handing, decontamination, packaging, and transfer from the transportable process to the reactor facility.

3. Preparation of feedstock material, both from the reactor facility and the glass former feedstock.

4. Sampling and analysis of the feedstock, glass product, and gaseous and liquid effluent discharge samples to the extent necessary to provide nuality control of the product and ensure operation within technical standards. 
The process is to be designed for an operating life of ten years. Equipment designed for less than ten-year life must be replaceable through removable panels. The melter itself must be designed for a three-year refractory and electrode life.

ARCHITECTURAL/STRUCTURAL REQUIREMENTS

All radioactive processing equipment and auxiliary support equipment associated with the operation of the transportable vitrification process are to be located in a minimum number of tractor/trailer units. The process is to be housed in not more than three semi-trailers of standard weight 1 imitations and dimensions. Gross weight limitations of each trailer is to be not in excess of $39,000 \mathrm{~kg}(86,000$ lbs) which includes the dry weight of the processing equipment, the trailer and its structural support, and the towing vehicle. Federal standards dictate the 1 imit at $36,000 \mathrm{~kg}(80,000 \mathrm{lbs})$, but the higher weight limit is acceptable in nearly all states by special permit. Maximum legal dimensions as prescribed by the highway standards are to be followed in the design of the system. The trailers are to have maximum dimensions of $48 \mathrm{ft}$ long by $13-1 / 2 \mathrm{ft}$ tall by $8-1 / 2 \mathrm{ft}$ wide. Ideally, all radioactive processing equipment is to be located within one trailer. If this cannot be achieved within the guidelines previously identified, then connecting radioactive waste streams must be transferred through double-contained pipelines to meet the double containment requirements described in the next paragraph.

All radioactive processing equipment and piping is to be contained under the double-containment philosophy. The radioactive equipment and piping serves as the first level of containment. The second level of containment is provided by a containment module whose ventilation system is separate of that of the ventilation system of the off-gas piping system. The containment module is to be desijned to operate at a minimum of 0.5 inches of water negative pressure. The containment module must also retain any liquid spills from the largest container in the process trailer. Liquid spills include slurries from the feed loop, off-gas scrubbing solution, and molten glass from the melter.

Operations are to be controlled from a control area in one of the trailer;. The control area is to be environmentally isolated from any 
radioactive processing areas or equipment. All equipment such as scrub pumps, melter electrical power switchgear, and feed or recirculation pumps that have the potential of generating radioactive material outside the first level of containment are to have emergency shutdown access from the central control area. Also, backup control and shutdown stations are to be provided for all crucial operating functions.

Provisions will be made in the radioactive processing areas for contact maintenance and personnel access. The radioactive processing areas include the feed recirculation system from the physical interface with the reactor facility to the point of entry into the melter; the melter system which includes the molten glass reservoir and associated refractory, steel shell, and electrical heating systems; the waste handling area which includes the turntabie containing the receiving canister, the decontamination station, and the overpack and transfer station; and the off-gas treatment system. Access for the removal of radioactive process equipment including all pumps and feed mechanisims and the melter unit will be provided by top access hatches. Major interrelated components should be designed on removable frames to minimize the dismantlement required for replacement of individual equipment items.

Provisions will be made in the design for radioactive shielding during processing to a level which has no significant impact to normal reactor operations as identified in the General Requirements. For purposes of design, the maximum dose rate outside the shielded area is to be kept at $100 \mathrm{mrem} / \mathrm{hr}$. The shielding may be designed as removable panels provided that sufficient decontamination of radioactive processing equipment can be achieved to allow transportation as low specific activity (LSA) material i $10 \mathrm{mrem} / \mathrm{hr} 2 \mathrm{~m}$ away from trailer).

All processing trailers including the control area and radioactive processing equipment and all support equipment must be able to be adapted for rail transport within the standard railroad guidelines. This may require the use of removable axles on the trailers and special hold downs on the rail car frame to comply with requirements for LSA shipment vehicles. 
MECHANICAL REQUIREMENTS

The of $f$-gas system is to be designed with adequate capacity to achieve the design throughput rates and to contain any surges in gaseous effluent rate from the melter that might occur. A design factor of three is to be used for noncombustible wet wastes and a design factor of eight is to be used for noncombustible slurries. The latter design basis is patterned after present high-level waste vitrification criteria. The different design factors, result from the fact that vitrification of noncombustible slurries occurs with a cold cap which is known to create occasional surges, whereas vitrification of combustibles does not operate with a cold cap resulting in a much more consistent effluent; release.

The ventilation system for the containment module is to maintain an adequate flow and negative pressure within the entire containment module to assure containment of any gaseous effluents or liquid aerosols from an of normal event. The design pressure for the containment module is $2.5 \mathrm{~cm}$ of water, although the normal operating pressure is $-1.3 \mathrm{~cm} \mathrm{H} \mathrm{H}_{2}$. The required flow rate through the containment module is the same as the off-gas system. The inlet and outlet air flows through the containment module are to be HEPA filtered so that in the event of a maximum effluent release from the melter, airborne contamination will be contained. The gaseous effluents from the containment module and off-gas treatment system are to be exhausted from the unit's own stack or may be exhausted to the reactor facility's ventilation system.

The trailers are to be constructed entirely of noncombustible materials. Automatic fire suppression systems will not be required in the trailers. However, at least two $A B C$ fire extinguishers will be mounted on or in each trailer.

An: cooling system requirements will be closed loop, either by removing heat to the external atmosphere or by preheating the feedstock. The transportable system will not rely on cooling services from the reactor facility. 


\section{ELECTRICAL}

Power

All electrical power necessary for operating the process will be supplied by its own portable power supply. The system will not rely on reactor facilities for electrical power. The main power supply, which powers the melter's electrical power and all support systems, will provide a minjmum of 500 KVA electrical power. In addition, a minimum 150 KVA backup power supply, independent of the main supply, will be provided to operate all systems other than electrical power to the melter in the event of main power faflure. Lighting

Flourescent, $110 \mathrm{~V}$ lighting will be provided in all normally occupied areas of the process trailers to meet OSHA requirements. Provisions for temporary or permanent lighting will be located in the radioactive process areas. If remote viewing is designed in these areas, permanent lighting will be provided. Outdoor lighting is not necessary for the enclosed process trailers, but incandescent outdoor lighting is required for atl trailers located outside a building enclosure (i.e., trailer containing electrical generators and heat exchange equipment).

Communications and Alarms

It is assumed that all fire, security, and evacuation alarms and telephone systems are provided and available at the reactor facility. However, an internal, audible intercom system is required in all trailers if more than one trailer is required to contain the process equipment.

Instrumentation

The process critical control parameters are to be adequately instrumented and alarmed so as to eliminate the potential for unintentional operator error. The critical and control parameters include those whose lack of control or monitoring would result in a release of radionuclides in excess of Table II, 10 CFR Part 20. 
This system is to be designed to meet the intent of Dccupational Safety and Health Administration (OSHA) requirements for safety during operations. Particular attention should be paid to exit and aisleway dimensions as a means of egress in event of an emergency.

\section{SECURITY}

Other than padlocks on the doors of the trailers, no additional security systems or procedures other than those already provided at the reactor facility will be required.

QUALITY ASSURANCE

The Quality Assurance Plan QAP-78 established for this program will be followed when preparing the design to ensure compliance of the design to this criteria. 

APPENDIX B

OPERATING COST ESTIMATE 
APPENDIX B

OPERATING COST ESTIMATE

PROJECTEO ANNUAL OPERATING COST

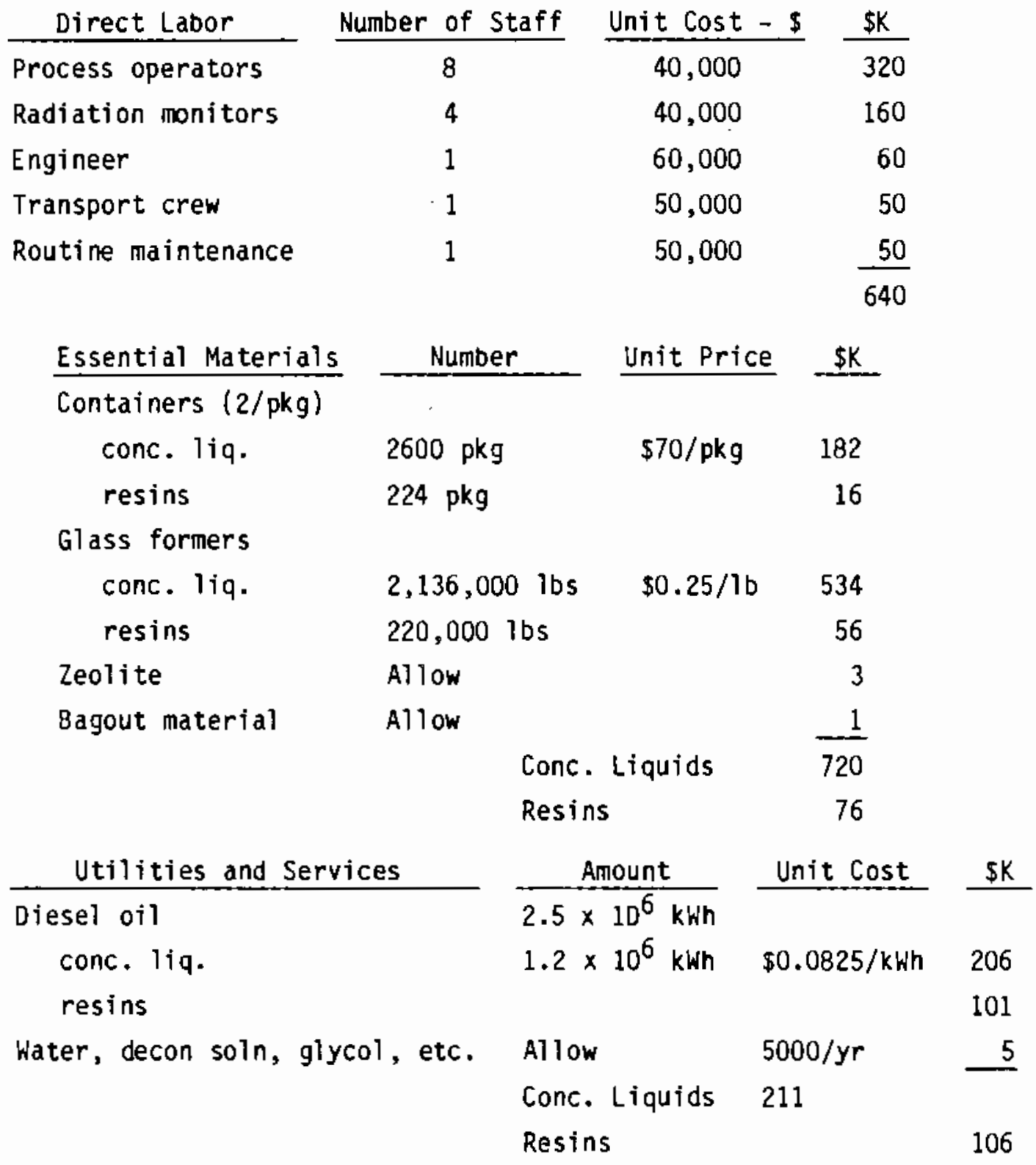


Nonroutine Maintenance

$0.11(\$ 4,200,000)$ and $0.33(500,000) \quad \underline{605}$

585

Miscellaneous Supplies \& Support Services 7

(640) $\times 0.01$

Travel Allowance

100

Total Conc. Liquids $\$ 2280 / \mathrm{yr}$ Resins

$\$ 1530 / \mathrm{yr}$ 
No. of

Copies

OFFSITE

30 DOE Technical Information Center

C. R. Cooley, RW-4

Geologic Repository Division

DOE Office of Civilian Radioactive Waste Management

Forrestal Building

Washington, DC 20585

2 DOE Office of Defense Waste 8 Byproducts Management GTN

Washington, DC 20545

ATTN: D. B. LeClaire, DP-12

R. D. Walton, Jr., DP-123

7 DOE Office of Terminal Waste Disposal \& Remedial Action GTN

Washington, DC 20545

Attn: J. E. Baublitz, NE-24

J. A. Coleman, NE-25

D. J. McGoff, NE-23

J. A. Turi, NE -25

W. R. Voigt, NE-20

H. F. Walter, NE -25

J. B. Zorn, NE-25

M. J. Bell

Division of Nuclear Materials Safety \& Safeguards

Ma-1 Station 881-SS

Nuclear Regulatory Commission

Washington, DC 20555

A. T. Clark

Division of

Nuclear Regulatory Commission

Washington, DC 20555
No. of

Copies

W. J. Dircks

Office of the Executive

Director for Operations

Mail Station 6209

Nuclear Regulatory Commission

Washington, DC 20555

2 Environmental Protection Agency

Office of Radiation Programs

401 M. Street, S.W.

Washington, DC 20460

ATTN : D. Egan

G. L. Sjoblom

2 DOE Albuquerque Operations Office

P.0. Box 5400

Albuquerque, $\mathrm{N}, \quad 87185$

ATTN: R. Y. Lowrey

J. McGough

W. H. Hannum

DOE West Valley Operations Office

P.0. Box 191

West Valley, NY 14171

3 DOE Idaho Operations Office

550 Second Street

Idaho falls, ID 83401

ATTN: J. D. Hamric

J. B. Whitsett

M. J. Barainca

M. R. Jugan

DOE Oak Ridge Operations Office P.0. Box E

Oak Ridge, TN 37830

S. A. Mann

DOE Chicago Operations Office

9800 South Cass Avenue

Argonne, IL 60439 
No. of

Copies

J. 0. Neff

DOE National Waste Program office

$505 \mathrm{King}$ Avenue

Columbus, $\mathrm{OH} \quad 43201$

G. K. Oertel

DOE Savannah River Operations office

P.0. Box A

Aiken, SC 29801

D. L. Vieth

DOE Nevada Operations Office P.0. Box 14100

Las Vegas, NY 89114

T. H. Row

Oak Ridge National Laboratory

P.0. Box $X$

Dak Ridge, TN 37830

3 Oak Ridge Nationa] Laboratory

P.0. Box Y

Oak Ridge, TN 37830

ATTN: J. 0. Blomeke

W. D. Burch

L. A. Dole

5 Sandia Laboratories

P.0. Box 5800

Albuquerque, $\mathrm{N}, \quad 87185$

ATTN: D. R. Anderson

J. F. Ney

R. W. Lynch

W. Weart

Technical Library

B. R. Wheeler

Westinghouse Idaho Nuclear

Co., Inc.

P.0. Box 4000

Idaho Falls, ID 83401
No. of

Copies

6 E. I. du Pont de Nemours \& Company, Inc.

Savannah River Laboratory

Aiken, SC 29801

ATTN: M. D. Boersma

J. L. Crandall

E. J. Hennelly

L. L. Kilpatrick/

L. M. Lee

S. Mirshak

R. M. Wallace

E. A. Jennrich

EG\&G Idaho

P.0. Box 1625

Idaho Falls, ID 83415

K. Y. Gilbert/P. G. Hagen

Rockwell International

Rocky Flats Plant

P.0. Box 464

Golden, CO 80401

G. W. Meyers

Atomics International 0ivision

Rockwell International

8900 DeSoto Avenue

Canoga Park, CA 91304

T. H. Pigford

Department of Nuclear

Engineering

University of California

Berkeley, CA 94720

R. Williams

Electric Power Research

Ins, ti tute

3412 Hillview Avenue

P.0. Box 10412

Pal Al to, CA 94304 
No. of

Copies

6 West Valley Nuclear Services Company

P.0. Box 191

West Valley, NY 14171

ATTN: C. C. Chapman

J. C. Cwynar

L. R. Eisenstatt

J. L. Knabenschuh

J. E. Krauss

J. M. Pope

W. A. Freeby/J. L. Jardine

Bechtel National, Inc.

P.0. Box 3965

San Francisco, CA 94119

Westinghouse Electric

Corporation

Technical Library

P.0. Box 207B

Carlsbad, NM 88220

R. G. Post

College of Engineering

University of Arizona

Tucson, AZ 85721

\section{ONSITE}

7 OOE Richland Operations Office

J. H. Anttonen

E. A. Bracken

P. A. Craig

M. J. Plahuta

J. L. Rhoades

M. W. Shupe

J. D. White

UNC: United Nuclear Industries

T. E. Dabrowski/W. J. Kyriazis

2 Westinghouse Hanford Company
No. of

Copies

11 Rockwell Hanford Operations

E. B. Ash

K. A. Gasper

R. N. Gurley

J. W. Patterson

R. D. Prosser

J. H. Roecker

K. R. Shah

M. J. Smith

T. B. Venziano

D. D. Wodrich

File Copy

Pacific Northwest Laboratory

W. H. Bjorklund

H. F. Bonner

R. A. Brouns

J. L. Buelt (20)

H. C. Burkholder

J. G. Carter

L. A. Chick

T. D. Chikalla

K. E. Eliason

M. S. Hanson

D. E. Knowlton

L. T. Lakey/K. M. Harmon

J. M. Latkovich

R. C. Liikala

A. H. McMakin

J. L. McElroy

J. E. Minor

J. M. Perez

K. J. Schneider

P. A. Scott

D. H. Siemens

W. R. Wiley/R. P. Marsha11/

D. B. Cearlock

B. M. Wise

D. J. Yeager

Technical Information (5)

Publishing Coordination (2)

R. E. Lerch

J. D. Watrous 


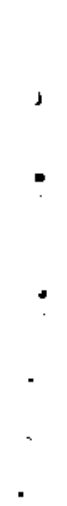

